Revista Eletrônica de Direito Processual - REDP. Volume 16. Julho a dezembro de 2015

Periódico Semestral da Pós-Graduação Stricto Sensu em Direito Processual da UERJ

Patrono: José Carlos Barbosa Moreira. ISSN 1982-7636. pp. 416-435 http://www.e-publicacoes.uerj.br/index.php/redp/index

\title{
APONTAMENTOS SOBRE HONORÁRIOS ADVOCATÍCIOS ${ }^{1}$
}

\section{NOTES ABOUT ATTORNEY'S FEES}

Orlando Luiz Zanon Junior

Doutor em Ciência Jurídica pela Univali. Dupla titulação em

Doutorado pela UNIPG, Itália. Mestre em Direito pela

UNESA. Pós-graduado pela UNIVALI e pela UFSC.

Professor da Escola da Magistratura de Santa Catarina (ESMESC), da Academia Judicial (AJ) e do Programa de Pós-graduação da UNIVALI. Juiz de Direito.

Clenio Jair Schulze Doutorando e Mestre em Ciência Jurídica pela UNIVALI.

Juiz Federal. clenio.schulze@trf4.jus.br

RESUMO: O texto aborda o sistema de honorários advocatícios brasileiro, visando tratar especificamente dos temas referentes à viabilidade (ou não) de condenação do sucumbente a indenizar a parte vencedora quanto ao valor dos honorários contratados, e, também, à previsão de fixação de verba de sucumbência em favor de advogado público.

PALAVRAS-CHAVE: Honorários Advocatícios. Advogado Público. Sucumbência.

ABSTRACT: This paper discusses the brazilian attorney's fees system, aiming to address the issues concerning, first, the viability (or not) of condemnation of the loser to compensate the winning party in the amount of the attorney's fees expedend by the winner, and also,

\footnotetext{
${ }^{1}$ Artigo recebido em 30/09/2015 e aprovado em 27/11/2015.
} 
Revista Eletrônica de Direito Processual - REDP. Volume 16. Julho a dezembro de 2015

Periódico Semestral da Pós-Graduação Stricto Sensu em Direito Processual da UERJ

Patrono: José Carlos Barbosa Moreira. ISSN 1982-7636. pp. 416-435

http://www.e-publicacoes.uerj.br/index.php/redp/index

second, the possibility of paying attorney's fees in favor of the public lawyers, in addition of his salary.

KEYWORDS: Attorneys' Fees. Public Lawyer.

\section{Introdução}

O objetivo do presente texto é discutir dois temas específicos sobre os honorários advocatícios no cenário jurídico brasileiro, quais sejam, primeiro aquele referente à viabilidade (ou não) de condenação do sucumbente a indenizar a parte vencedora quanto ao valor dos honorários contratados com seu procurador, e, segundo, no tocante à previsão de fixação de verba de sucumbência em favor de advogado público.

A análise considerará uma abordagem integrada da remuneração das diversas funções do sistema judicial (juízes, promotores de justiça, defensores públicos e advogados, principalmente), de acordo com as peculiaridades do cenário brasileiro.

No ponto, cabe referir que o sistema jurídico brasileiro é um dos mais pródigos do mundo. Muito disto decorre do grande número de profissionais que atuam no cenário forense. Sem embargo, estima-se que existem, no Brasil, aproximadamente dezessete mil juízes, doze mil membros dos Ministérios Públicos (federal e estadual) e quase um milhão de advogados. Há ainda milhares de outros profissionais que atuam no universo jurídico. É inegável que este alto número contribui para o volume de processos judiciais em tramitação.

Atualmente há aproximadamente cem milhões de processos em tramitação no Judiciário brasileiro ${ }^{2}$. Significa que há, em média, um processo para cada dois habitantes. Esta é a real fotografia da crise do Estado (pós) social, decorrente de uma exagerada expectativa quanto à capacidade do Estado-Juiz de resolução de todos os problemas da Sociedade. É a prova, portanto, de que o bacharelismo triunfou no Brasil.

\footnotetext{
2 CNJ. Relatórios Justiça em Número/Conselho Nacional de Justiça - Brasília: CNJ 2014. Disponível em: $\quad$ http://www.cnj.jus.br/programas-de-a-a-z/eficiencia-modernizacao-e-transparencia/pj-justica-emnumeros/relatorios. Acessado em 03 de outubro de 2015.
} 
Revista Eletrônica de Direito Processual - REDP. Volume 16. Julho a dezembro de 2015

Periódico Semestral da Pós-Graduação Stricto Sensu em Direito Processual da UERJ

Patrono: José Carlos Barbosa Moreira. ISSN 1982-7636. pp. 416-435 http://www.e-publicacoes.uerj.br/index.php/redp/index

Neste contexto, o presente artigo analisa um dos aspectos inerentes ao sistema de Justiça, atinente à remuneração profissional sob a forma de honorários advocatícios.

Para tanto, o primeiro item do texto desmistifica a noção técnica de honorários advocatícios para, nos itens posteriores, tratar dos temas referentes à viabilidade (ou não) de condenação do sucumbente a indenizar a parte vencedora quanto ao valor dos honorários que ela ajustou com seu procurador, e, também, à previsão de fixação de remuneração sucumbencial em favor de advogado público.

\section{Breves considerações iniciais sobre os Honorários Advocatícios}

Antes de inaugurar a discussão sobre os dois tópicos selecionados, cabe desmistificar um detalhe sobre o entendimento concernente aos honorários advocatícios, para esclarecer que possui a natureza de contraprestação única por um serviço específico e determinado, ainda que possa nascer de origens diversas. Deste modo, a inserção de uma condenação automática no dispositivo sentencial não significa uma remuneração diversa por um mesmo serviço, mas sim consubstancia a responsabilização cível do litigante perdedor a remunerar o vitorioso das despesas que efetuou (pelo simples fato da derrota, independentemente de culpa), ainda que a legislação atribua tal parcela também ao advogado como prêmio de desempenho, adicionando o critério da meritocracia aos da causalidade e da sucumbência ${ }^{3}$.

Sem embargo, atualmente, a legislação brasileira prevê três formas de nascimento da obrigação ao pagamento de honorários advocatícios, uma de origem contratual e outra de ordem sucumbencial, sem prejuízo daqueles arbitrados pelo exercício da função de defensor dativo, consoante arts. 20 do CPC e 22 da Lei 8.906/1994.

A leitura de tais preceitos legais poderia levar à impressão de que existem diversas "modalidades" de honorários advocatícios, quando, em verdade, estes consubstanciam um

3 CAHALI, Yussef Said. Honorários advocatícios. 3 ed. São Paulo: RT, 1997. p. 51: [Sobre a conjugação entre os critérios da sucumbência e da causalidade no cenário brasileiro] "Na lição de Carnelutti, válida para nosso Direito, a raiz da responsabilidade está na relação causal entre o dano e a atividade de uma pessoa. Esta relação causal é denunciada segundo alguns indícios, o primeiro dos quais é a sucumbência; não há aqui nenhuma antítese entre o princípio da causalidade e a regra da sucumbência como fundamento da responsabilidade pelas despesas do processo: se o sucumbente as deve suportar, isto acontece porque a sucumbência demonstra que o processo teve nele a sua causa. Mas o princípio da causalidade é mais largo do que aquele da sucumbência, no sentido de que esta é apenas um dos indícios da causalidade". 
Revista Eletrônica de Direito Processual - REDP. Volume 16. Julho a dezembro de 2015

Periódico Semestral da Pós-Graduação Stricto Sensu em Direito Processual da UERJ

Patrono: José Carlos Barbosa Moreira. ISSN 1982-7636. pp. 416-435 http://www.e-publicacoes.uerj.br/index.php/redp/index

conceito operacional único de remuneração profissional por um serviço específico, sendo apenas o modo de nascimento da obrigação jurídica que difere.

Ou seja, é muito importante verificar que efetivamente não existem tipos distintos de remuneração advocatícia, a qual é uma só e decorre do relevante exercício de função essencial ao bom desempenho do sistema judicial, mas sim existem formas distintas do nascimento da obrigação de pagamento ao profissional.

Em síntese, há um serviço profissional prestado e, de outro lado, a respectiva contraprestação, com origens diferentes.

Fixada esta primeira premissa, cabe mencionar que a remuneração do advogado pelos serviços prestados é contratada diretamente com o seu cliente, mediante ajuste que estabelece o montante e as formas de pagamento. Ou seja, o nascimento da remuneração profissional é contratual, estando diretamente relacionada com o serviço de consultoria ou contencioso prestado e a projeção do nome do profissional no mercado. Em consequência, trata-se de uma parcela única de natureza contratual (ou seja, de cunho eminentemente privado), fixada em favor especificamente do causídico que prestou os serviços de assessoramento e/ou acompanhamento processual.

Porém, em se tratando especificamente de serviços de acionamento do sistema judicial (e não apenas consultivos), a legislação processual geralmente estabelece que a parte possa ser indenizada de tal despesa, acaso seja confirmado seu interesse em juízo, mediante a inclusão de uma parcela indenizatória de forma automática no dispositivo sentencial, na exata proporção de sua vitória/derrota, com base no instituto da responsabilização cível objetiva do sucumbente, consoante a articulação dos critérios da sucumbência e da causalidade $^{4}$. Isto não significa que nasce uma segunda remuneração advocatícia (até sob pena de bis in idem), mas sim que o cliente pode ser indenizado das despesas que efetuou, desde que dentro de estritos limites fixados sob controle jurisdicional, considerando que a parte não interviu pessoalmente na escolha (e no preço) do advogado contratado pela

4 THEODORO JÚNIOR, Humberto. Curso de direito processual civil. V. 1. 47 ed. Rio de Janeiro: Forense, 2007. p. 106: “Ainda que não haja pedido expresso do vencedor é devido o ressarcimento dos honorários de seu advogado. [...] É que o pagamento dessa verba não é o resultado de uma questão submetida ao juiz. Ao contrário, é uma obrigação legal, que decorre automaticamente da sucumbência, de sorte que nem mesmo ao juiz é permitido omitir-se frente a sua incidência" (grifou-se). 
Revista Eletrônica de Direito Processual - REDP. Volume 16. Julho a dezembro de 2015

Periódico Semestral da Pós-Graduação Stricto Sensu em Direito Processual da UERJ

Patrono: José Carlos Barbosa Moreira. ISSN 1982-7636. pp. 416-435 http://www.e-publicacoes.uerj.br/index.php/redp/index

contraparte vitoriosa. Outrossim, a verba honorária é uma só, porém, o litigante vitorioso pode ser indenizado daquilo que despendeu para estar em juízo.

Todavia, no cenário brasileiro, a legislação processual estabeleceu que tal direito indenizatório não deve ser atribuído à parte vencedora, mas sim ao seu próprio advogado diretamente, como um prêmio de desempenho adicional, por ter auxiliado na obtenção da vitória, adicionando o critério da meritocracia aos da causalidade e da sucumbência.

Daí que os honorários advocatícios previamente contratados e, depois, indenizados via sucumbência são, ambos, direcionados ao advogado. Em outras palavras, em uma análise histórica, os advogados conquistaram a indenização que pertenceria à parte, como uma prerrogativa justificada em seu desempenho profissional, de modo a serem remunerados duplamente pelo mesmo serviço. Ou seja, a remuneração única por um mesmo serviço específico e delimitado é atribuída duas vezes ao procurador, tanto na origem contratual como também, depois, na respectiva indenização que, a rigor, caberia a parte vencedora, com lastro em uma opção legislativa lastrada na meritocracia (no resultado positivo atingido). Sem embargo, o ponto de sustentação mais sólido para tal modificação da titularidade da reparação cível, atualmente prevista na legislação brasileira, reside na tese de que os honorários advocatícios nascidos no dispositivo sentencial merecem ser destinados ao profissional que, exercendo revelante função social e de auxílio essencial à jurisdição, ajudou a parte a obter a vitória, de modo a justificar que a indenização não seja destinada a quem sofreu um dano, mas sim àquele que se empenhou em repará-lo.

Yusef Said Cahali, em posição levemente diferente daquela anunciada no parágrafo anterior, ao discorrer sobre a modificação operada pelo art. 23 da Lei 8.906/1994, argumentou que a verba de patrocínio fixada na sentença teria perdido a sua histórica natureza indenizatória, para assumir feição puramente remuneratória, no cenário jurídico brasileiro $^{5}$. Porém, com todo o respeito, tal conclusão não parece correta.

Primeiro, porque negar a origem indenizatória aos honorários nascidos da sucumbência implicaria, por consequência, aceitar que a condenação do vencido deixaria de repousar na articulação entre os princípios da causalidade e da sucumbência, para constituir

5 CAHALI, Yussef Said. Honorários advocatícios. 3 ed. São Paulo: RT, 1997. p. 803-804. 
Revista Eletrônica de Direito Processual - REDP. Volume 16. Julho a dezembro de 2015

Periódico Semestral da Pós-Graduação Stricto Sensu em Direito Processual da UERJ

Patrono: José Carlos Barbosa Moreira. ISSN 1982-7636. pp. 416-435 http://www.e-publicacoes.uerj.br/index.php/redp/index

uma obrigação material do vencido em remunerar o advogado da parte contrária pelos serviços que prestou em favor somente dela, fazendo nascer um instituto jurídico contraditório e desvinculado de suas tradições. Ora, não é razoável entender que o litigante perdedor, pelo simples fato da sua derrota e sem incorrer em quaisquer das hipóteses de nascimento de obrigações jurídicas, receba o encargo processual de custear a remuneração material pelo serviço prestado a outrem, como uma reprimenda adicional por ter seus interesses subjugados. Acaso vingasse tal tese, a verba advocatícia de origem sucumbencial consubstanciaria uma espécie de sanção pelo exercício do direito constitucional de acesso à jurisdição, porque alguém entrou em juízo (ou formulou defesa) e, depois, perdeu a causa. Em consequência, seria preciso admitir que deixaria de ser uma honraria paga ao profissional que auxiliou na vitória, para se tornar um custo extra pela desonraria da derrota.

E, segundo, porque os honorários advocatícios de origem sucumbencial, acaso efetivamente não decorressem do efeito indenizatório do dispositivo sentencial, deixariam de se fundamentar na causalidade inerente ao processo e, então, passariam a ter caráter substantivo, constituindo crédito pertencente ao causídico que, então, inegavelmente seria litisconsorte do seu cliente quanto à parcela da pretensão deduzida em juízo. Ora, se os honorários tivessem deixado de ser indenização fundada na causalidade processual, assumiriam o caráter de obrigação remuneratória material, de modo a restar inafastável se considerar que o advogado seria também parte na relação processual, afinal, postularia uma remuneração material independente e autônoma perante a parte adversa, em uma flagrante descaracterização de sua importante função no sistema judicial.

Daí que, em razão destes motivos, mais adequado é permanecer com a orientação exposta no presente artigo científico, no sentido de que, consoante a legislação brasileira mencionada, a condenação sucumbencial em honorários advocatícios continua tendo como base a responsabilização cível objetiva do litigante perdedor (pelo simples fato da sua derrota), de acordo com articulação dos postulados da causalidade e da sucumbência, ainda que a titularidade do crédito seja deslocada da parte vencedora para o seu advogado, como prêmio de desempenho.

Estabelecidas estas premissas iniciais, cabe ingressar na análise dos dois assuntos objeto do presente artigo, nos itens subsequentes. 
Revista Eletrônica de Direito Processual - REDP. Volume 16. Julho a dezembro de 2015

Periódico Semestral da Pós-Graduação Stricto Sensu em Direito Processual da UERJ

Patrono: José Carlos Barbosa Moreira. ISSN 1982-7636. pp. 416-435 http://www.e-publicacoes.uerj.br/index.php/redp/index

\section{Condenação do sucumbente em indenização cível por contratação de advogado}

Atualmente, têm se intensificado as discussões acerca da possibilidade de se incluir na condenação uma segunda parcela indenizatória de honorários advocatícios, desta vez em favor da parte devedora, que historicamente havia perdido o direito à indenização sucumbencial em favor do advogado, nos termos do arts. 22 da Lei 8.906/1996.

Tal tese não merece prevalecer, devendo ser mantido o entendimento de que a parte perdedora somente pode ser sucumbente quanto a uma única parcela remuneratória em favor do advogado da parte adversa, na extensão de sua derrota, haja vista que, primeiro, não é viável a dupla condenação indenizatória, em favor do causídico e também adicionalmente da parte; e, segundo, de acordo com a configuração jurídica atual da sucumbência, a remuneração de procurador consubstancia um encargo negocial intransferível a outrem.

No tocante ao primeiro argumento, destaca-se ser inadequado que a parte derrotada indenize a remuneração do advogado, que é uma só, por duas vezes somadas, uma em favor dele e outra em favor da parte que representou.

Isto porque a indenização da remuneração profissional é única, de modo que a legislação pode fixar em favor da parte ou, alternativamente, como ocorre no caso da legislação processual brasileira, em favor do advogado, como um prêmio de desempenho. Como consequência, a parte derrotada não pode ser condenada a custear duplamente a indenização da verba honorária, sob pena de se estabelecer três hipóteses de nascimento da remuneração profissional por um mesmo serviço, uma contratual (originária) e outra indenizatória duplicada (sucumbencial), esta última dividida em uma parcela em favor do advogado e repetida também em favor da parte, em flagrante bis in idem.

Segundo a lógica aqui exposta, a indenização fixada na sucumbência deve ser uma só, cabendo à legislação estabelecer se merece ser atribuída em favor da parte vencedora ou, alternativamente, em favor do advogado a título de prêmio de desempenho (como no cenário brasileiro), sendo inviável a condenação dobrada em favor de ambos.

Adotando justamente tal posicionamento, o Tribunal de Justiça de Santa Catarina já definiu que "as despesas contraídas pelo autor com o recolhimento das custas processuais e com a contratação de advogado não podem ser objeto de indenização por danos materiais, 
Revista Eletrônica de Direito Processual - REDP. Volume 16. Julho a dezembro de 2015

Periódico Semestral da Pós-Graduação Stricto Sensu em Direito Processual da UERJ

Patrono: José Carlos Barbosa Moreira. ISSN 1982-7636. pp. 416-435 http://www.e-publicacoes.uerj.br/index.php/redp/index

porque já abrangidas na distribuição do ônus da sucumbência, sendo vedada a dupla penalização do litigante vencido" (TJSC, AC 2007.042314-4, Jânio Machado, 14.11.2007; grifou-se).

Ademais, cabe suscitar um segundo argumento para inviabilizar a indenização duplicada, no sentido de que a verba gasta com contratação de advogado consubstancia encargo decorrente de opção negocial particular, de modo que é inviável a sua transferência para outrem. Entendimento contrário ensejaria uma dupla condenação ao vencido em verba honorária (decorrente da bifurcação da verba em duas partes - contratual e sucumbencial), cujo importe ficaria ao livre talante da parte adversa na escolha do profissional ou, alternativamente, ao arbítrio de tabela de órgão profissional que não necessariamente reflete as variações e características do mercado.

Com base especificamente neste segundo argumento, a Corte Catarinense já definiu que "não é cabível o ressarcimento dos danos decorrentes da contratação do advogado para ajuizamento da demanda por se tratar de um negócio jurídico particular que decorre de liberalidade das partes e não vincula a parte adversa" (TJSC, AC 2013.051584-8, Fernando Carioni, 03.09.2013; grifou-se).

Por fim, cabe mencionar que o Superior Tribunal de Justiça adota uma terceira linha argumentativa para afastar a possibilidade de ressarcimento dos honorários contratuais, lastrada na tese de que não há ilícito que justifique a repetição do indébito.

Notadamente, o entendimento da Corte de Superposição é no sentido de que "os custos decorrentes da contratação de advogado para ajuizamento de ação, por si só, não constituem ilícito capaz de ensejar danos materiais indenizáveis" (STJ, AgRg no AREsp 477296 / RS, Antônio Carlos Ferreira, 16.12.2014).

Com efeito, "o entendimento desta Corte [STJ] é que a mera contratação de advogado para defesa judicial dos interesses da parte não enseja, por si só, dano material passível de indenização, porque inerente ao exercício regular dos direitos constitucionais do contraditório, da ampla defesa e do acesso à Justiça" (STJ, AgRg no REsp 1507864 / RS, Moura Ribeiro, 17.09.2015). 
Revista Eletrônica de Direito Processual - REDP. Volume 16. Julho a dezembro de 2015

Periódico Semestral da Pós-Graduação Stricto Sensu em Direito Processual da UERJ

Patrono: José Carlos Barbosa Moreira. ISSN 1982-7636. pp. 416-435 http://www.e-publicacoes.uerj.br/index.php/redp/index

Por fim, cabe salientar que também a lição de Yussef Said Cahali reforça a ideia de que "não são reembolsáveis, a título de honorários, as despesas que a parte enfrenta em razão do ajuste com o profissional a título de honorários, para o patrocínio da causa" 6 .

Desta forma, conclui-se que o sistema jurídico brasileiro não permite a indenização adicional à sucumbencial por contratação de advogado, por violação à principiologia básica referente à responsabilização cível e à reparação das despesas processuais.

\section{Honorários de Sucumbência ao Advogado Público}

Este terceiro item trata da questão referente à fixação de honorários especificamente aos advogados públicos, ou seja, aos profissionais ocupantes de cargos públicos remunerados pelo erário para, com exclusividade, prestar assessoria e representar judicialmente os entes e órgãos estatais.

Uma análise do sistema jurídico brasileiro revela ser inadequada a condenação da parte ao pagamento de tal verba em se tratando de processo vencido por ente estatal patrocinado por seu advogado público, haja vista que, em primeiro lugar, a remuneração adicional por honorários aos advogados públicos, ainda que possa estimular o desempenho, vem em contrariedade à mentalidade de preservação de interesse coletivo que merece reger a atuação dos agentes públicos (notadamente os ocupantes de carreiras de Estado), em ofensa ao princípio da moralidade estabelecido no art. 37 da CRFB.

A percepção de verba honorária a título de prêmio de desempenho, apesar de tender a estimular o ânimo subjetivo de vitória processual, atenta contra a postura profissional que merece reger as carreiras estatais, voltadas ao interesse coletivo e não ao aumento de ganhos pessoais. Notadamente, em que pese o prêmio de desempenho na atividade privada certamente configurar um louvável estimulo à meritocracia, de outro lado, na esfera pública pode representar um perigoso desvirtuamento do enfoque do agente estatal, que deixaria de visar estritamente o interesse da coletividade em prol da busca da lucratividade pessoal, podendo resultar em invasão a direitos individuais.

6 CAHALI, Yussef Said. Honorários advocatícios. 3 ed. São Paulo: RT, 1997. p. 418-419. 
Revista Eletrônica de Direito Processual - REDP. Volume 16. Julho a dezembro de 2015

Periódico Semestral da Pós-Graduação Stricto Sensu em Direito Processual da UERJ

Patrono: José Carlos Barbosa Moreira. ISSN 1982-7636. pp. 416-435 http://www.e-publicacoes.uerj.br/index.php/redp/index

Ora, em uma análise histórica específica dos agentes públicos ligados à área jurídica, verifica-se que lhes é vedada a percepção de qualquer prêmio de desempenho pelo exercício de sua função, como forma justamente de evitar que invadam a esfera de particulares com o intuito de majorar sua remuneração, desvirtuando sua função pública. Notadamente, os honorários representam um prêmio de desempenho incompatível com o exercício da atividade pública, ante os efeitos deletérios que podem causar.

Como exemplos, é possível argumentar que a atribuição de um prêmio de desempenho aos policiais que aplicarem multas de trânsito pode até resultar em uma fiscalização mais intensa nas vias públicas, porém, certamente, ensejará uma postura excessivamente incisiva do servidor em face dos particulares, de modo a desnaturar sua função de servir à coletividade para dar lugar ao ímpeto de majorar sua remuneração.

Da mesma forma, conceder honorários aos auditores fiscais que mais coletarem tributos, embora possa elevar a arrecadação e diminuir a sonegação, pode ensejar a desvirtuação de sua atuação voltada à coleta de tributos de forma justa para uma atitude proativa de aumentar a entrada de recursos a qualquer custo, como meio de enriquecer.

Notadamente, os exemplos oferecidos não negam que a meritocracia é um importante critério para fixação de parâmetros de remuneração profissional e de projeção nas carreiras, sendo muito comum no cenário privado. Porém, embora também mereça ser incentivado no âmbito público, é preciso ser criteriosamente reservado para situações específicas, para evitar que se volte contra os interesses dos próprios contribuintes, como narrado nas hipóteses acima. Sem dúvida, a fixação de remuneração de agente público que implique exacerbação da ostensividade em face do particular é um destes casos em que a meritocracia pode se revelar contrária ao interesse coletivo, tanto que se trata de uma janela gradualmente fechada ao longo da história, cuja reabertura ofende a principiologia ética constitucional.

E, no sentido pragmático, não há como negar que a atuação dos advogados públicos remunerados também cumulativamente por honorários de desempenho, certamente, deixará de poder ser talvez considerada uma atividade de Estado para assumir um perfil empresarial, consistente em aproveitar este novo "nicho de mercado", caracterizado pela exclusividade da defesa estatal (que, aí, se tornaria um privilégio, ou seja, um monopólio lucrativo desta atividade). 
Revista Eletrônica de Direito Processual - REDP. Volume 16. Julho a dezembro de 2015

Periódico Semestral da Pós-Graduação Stricto Sensu em Direito Processual da UERJ

Patrono: José Carlos Barbosa Moreira. ISSN 1982-7636. pp. 416-435 http://www.e-publicacoes.uerj.br/index.php/redp/index

Tanto é assim que foi vedado aos juízes receber honorários das partes pelo número ou qualidade de sentenças dadas, bem como sendo-lhes proibido receber custas processuais ou embolsar eventuais prêmios de gratidão que as partes possam lhes dar. Há certamente um motivo ético para afastar a meritocracia, nestes termos, da atividade jurisdicional. Ao contrário dos árbitros, os juízes estatais não recebem valores das partes, mas apenas a remuneração fixa, em prol dos serviços que prestar, de modo a obstar que atuem voltados a ganhos, na forma empresarial, que embora seja postura muito estimulante no mercado privado, pode gerar efeitos deletérios quando interesses públicos entram em pauta.

Da mesma forma ocorre com o Ministério Público, que recebeu responsabilidades políticas relevantes e, portanto, apesar de atuar como representante de determinados interesses em processos, não se lhe atribui o prêmio de desempenho pago pelas partes, a título de honorários pelas ações em que restar vitorioso ${ }^{7}$.

Também os Defensores Públicos devem atuar sem receber prêmio de desempenho custeado pelas partes, pois a condução ética de seu trabalho implica a vinculação a interesses coletivos, não consistindo em vencer a qualquer custo para fim de obter maior remuneração.

Daí que, acaso se aceite que os advogados públicos podem receber prêmio de desempenho pago diretamente pela parte, pela prestação de um serviço público, da mesma forma teria de ser aceito que poderia ser instituído o prêmio de desempenho pago também pelas partes aos membros do Ministério Público (honorários em ações civis públicas, por exemplo), aos integrantes da Defensoria Pública (honorários advocatícios pela defesa dos hipossuficientes) e também aos Juízes (mediante repasse das custas processuais ou a fixação de honorário por sentença de mérito, por exemplo).

Aliás, atribuir remuneração ao juiz pela quantidade de sentenças dadas não seria tão nocivo ao equilíbrio de forças processuais (paridade de armas) quanto a fixação de honorários para as demais carreiras, porquanto acarretaria um reflexo só quantitativo (estímulo a terminação de feitos propostos por outrem, com vista à majoração de

7 MENDES, Gilmar Ferreira. COELHO, Inocêncio Mártires. BRANCO, Paulo Gustavo Gonet. Curso de direito constitucional. 4 ed. São Paulo: Saraiva, 2009. p. 1041: “A Constituição lista, ainda, proibições aos membros do Ministério Público, sempre orientadas ao propósito de fortificar a própria Instituição. Veda situações capazes de pôr em risco a autonomia planejada. Assim, os membros não podem receber honorários ou custas processuais, não podem exercer advocacia nem exercer outra função pública ou privada ou atividade política-partidária”. 
Revista Eletrônica de Direito Processual - REDP. Volume 16. Julho a dezembro de 2015

Periódico Semestral da Pós-Graduação Stricto Sensu em Direito Processual da UERJ

Patrono: José Carlos Barbosa Moreira. ISSN 1982-7636. pp. 416-435 http://www.e-publicacoes.uerj.br/index.php/redp/index

rendimentos), ao invés de desvelar um aspecto preponderantemente lucrativo (estímulo a obtenção de vitórias dos entes estatais perante o particular, com intuito de ganhos pessoais).

Portanto, de acordo com os fundamentos acima expostos, é inconstitucional a fixação de honorários em favor dos advogados públicos, sob pena de ofensa à principiologia que rege o funcionamento das carreiras estatais, notadamente desvirtuando os postulados da eficiência e da moralidade, previstos no art. 37, caput, da CRFB, em detrimento do próprio interesse coletivo.

Em segundo lugar, igualmente é inconstitucional a majoração da remuneração do advogado público mediante o acréscimo também de honorários, por implicar desequilíbrio na fixação da verba de contraprestação no âmbito do serviço público, em contradição ao art. $39, \S 1^{\circ}$, I a III, da CRFB, o qual estabelece os critérios para fixação da remuneração dos agentes públicos.

Notadamente, a remuneração dos exercentes de funções, empregos e cargos públicos já é devidamente fixada na legislação de acordo com a natureza do serviço, a complexidade das suas atividades, os requisitos para investidura, as peculiaridades da função e, notadamente, o grau de responsabilidade, nos estritos termos do preceito constitucional antes exposto. Daí que a percepção de valores adicionais implica a majoração da remuneração do profissional de forma contingente (a depender da variação em vitórias), gerando um desequilíbrio na fixação legal da remuneração.

Ademais, com o devido respeito e consideração a todas as profissões do cenário jurídico, é preciso assinalar que a maioria exerce atividades de natureza e complexidade similar - o que significa inexistir razão para uma delas (especificamente os advogados públicos) receber, além da remuneração por parcela única, também os honorários, de modo a viabilizar a ampliação de seus ganhos para acima dos demais agentes deste ramo de atuação. Isto para evitar entrar no mérito da discussão com relação às diversas modalidades de limitações e ao grau de responsabilidade política impostos aos diferentes profissionais da área, considerando os efeitos que suas decisões efetivamente geram na regência das condutas em Sociedade.

Ora, a remuneração do agente público mediante uma segunda parcela remuneratória, consistente em honorários advocatícios, desequilibra os parâmetros constitucionais para 
Revista Eletrônica de Direito Processual - REDP. Volume 16. Julho a dezembro de 2015

Periódico Semestral da Pós-Graduação Stricto Sensu em Direito Processual da UERJ

Patrono: José Carlos Barbosa Moreira. ISSN 1982-7636. pp. 416-435 http://www.e-publicacoes.uerj.br/index.php/redp/index

remuneração dos agentes públicos, ao estabelecer uma classe de profissionais que, por um mesmo serviço público, recebe do erário e, também, de forma direta dos contribuintes processados, podendo implicar a majoração de sua remuneração para acima dos subsídios dos membros de poderes estatais (Presidente da República, Congressistas e Juízes) e dos integrantes do Ministério Público, os quais atuam com elevada carga de responsabilidade política.

Acaso vingasse a tese de que os advogados públicos, além de receber considerável subsídio (em algumas situações igual ou superior à remuneração do Juiz, do Promotor de Justiça e do Defensor Público), fosse também remunerado por vultuosa quantia decorrente de honorários por desempenho (no caso de vitória), ocorreria um considerável desequilíbrio remuneratório, mormente considerando o montante das verbas envolvidas nas ações públicas.

Ademais, implica uma injusta soma do "melhor de dois mundos", ao thes fixar as vantagens tanto da atividade pública com aquelas do exercício da profissão de advogado no mercado, sem estar submetido a todas as limitações e dificuldades encontradas nos dois cenários. Ora, haveria uma classe de servidores públicos que, por um mesmo serviço, ganharia a remuneração estatal e, ainda também, o pagamento de verba extra em decorrência da reserva de mercado para advocacia dos entes públicos. Em uma visualização cenográfica, numa mesma sala de audiência, haveria um magistrado que receberia só por subsídio, um advogado particular que perceberia apenas os honorários e, de ou outro lado, um procurador público que ganharia a verba dos outros dois somadas.

Em terceiro lugar, é inconstitucional a interpretação da legislação processual que acarrete a dupla remuneração do advogado público, mediante subsídio estatal em parcela única e também indenização sucumbencial de cunho privado, por ofensa aos arts. $39, \S 4^{\circ}$, e 135 da CRFB.

Notadamente, os preceitos constitucionais acima indicados estabelecem que a remuneração dos advogados públicos será efetuada mediante subsídio, da mesma forma que os agentes políticos, ou seja, em parcela única e vedado o acréscimo de quaisquer parcelas adicionais, razão pela qual não é viável que recebam um elemento adicional de remuneração também por honorários advocatícios. Ou seja, independentemente do teto fixado no art. 37, 
Revista Eletrônica de Direito Processual - REDP. Volume 16. Julho a dezembro de 2015

Periódico Semestral da Pós-Graduação Stricto Sensu em Direito Processual da UERJ

Patrono: José Carlos Barbosa Moreira. ISSN 1982-7636. pp. 416-435 http://www.e-publicacoes.uerj.br/index.php/redp/index

XI, da CRFB, é inviável a cumulação de rendimentos, mesmo que abaixo de tal valor, por implicar ofensa à disposição constitucional que estabelece o subsídio em parcela fixa e sem elementos remuneratórios adicionais.

Notadamente, o advogado público merece ser remunerado por subsídio fixado em parcela única, não comportando elementos remuneratórios adicionais, a exemplo de honorários advocatícios. Mesmo que a remuneração específica do advogado não receba ainda o título de subsídio, é certo que deve ser atendido tal regime constitucional para pagamento dos agentes públicos da área jurídica, sendo vedada a inserção de uma nova modalidade vencimental.

Isto porque a remuneração por subsídio pressupõe "pagamentos mensais de parcelas únicas, ou seja, indivisas e insuscetíveis de acréscimos de qualquer espécie". ${ }^{8}$ Aliás, não há divergência doutrinária quanto ao fato de que justamente "a característica fundamental do subsídio está na sua fixação em parcela única, conforme dispõe o $\S 4^{\circ}$ do art. 39 da CF, vedado o acréscimo de qualquer gratificação, adicional, abono, prêmio, verba de representação ou outra espécie remuneratória" ". E, também "ao falar em parcela única, fica clara a intenção de vedar a fixação dos subsídios em duas partes, uma fixa e outra variável"10. Daí que, em síntese, todos aqueles submetidos ao regime de remuneração em tela "não poderão receber outra remuneração que não o próprio subsídio, considerando-se assim repita-se - como a única parcela devida como contraprestação do trabalho por eles desempenhado"11.

Daí que, de acordo com tais ensinamentos doutrinários, é inviável que o advogado público acumule as rendas de sua atividade pública com um prêmio de desempenho de cunho privado, custeado pela eventual pessoa da coletividade atingida por sua atividade.

No ponto, não se desconhece o argumento de que não haveria incompatibilidade na dupla remuneração, mediante subsídios e também honorários, pelo fato de que as fontes

8 MELLO, Celso Antônio Bandeira de. Curso de direito administrativo. 26 ed. São Paulo: Malheiros, 2009. p. 268.

9 MEDAUAR, Odete. Direito administrativo moderno. 13 ed. São Paulo: RT, 2009. p. 280.

10 DI PIETRO, Maria Sylvia Zanella. Direito administrativo. 26 ed. São Paulo: Atlas, 2013. p. 611.

11 CANOTILHO, J. J. Gomes. MENDES, Gilmar Ferreira, SARLET, Ingo Wolfgang. STRECK, Lenio Luiz. (Coords.). Comentários à Constituição do Brasil. São Paulo: Saraiva/Almedina, 2013. p. 942. 
Revista Eletrônica de Direito Processual - REDP. Volume 16. Julho a dezembro de 2015

Periódico Semestral da Pós-Graduação Stricto Sensu em Direito Processual da UERJ

Patrono: José Carlos Barbosa Moreira. ISSN 1982-7636. pp. 416-435

http://www.e-publicacoes.uerj.br/index.php/redp/index

pagadoras podem eventualmente não ser as mesmas ${ }^{12}$. Porém, evidentemente que tal tese é insustentável, haja vista que a origem da verba não merece ser analisada no sentido puramente econômico (a fonte pagadora), mas sim preponderantemente no contexto jurídico (a origem do pagamento), pois ambas as remunerações (subsídios e honorários), embora custeadas por pessoas diversas (o Estado ou o contribuinte processado), tem a origem no exato mesmo trabalho realizado, que é justamente um serviço de advocacia fornecido ao ente público (com o privilégio de exclusividade). Daí que, por este mesmo serviço, o advogado público não merece ser remunerado duas vezes, sob pena de quebra ao sistema de rendimento único, decorrente do modelo vencimental fixado ao agente público.

Não é ocioso ainda destacar que o mesmo argumento repelido no parágrafo anterior, no sentido de desvinculação dos honorários advocatícios quanto ao regime de subsídio, implicaria, por vias oblíquas, que o advogado público não estaria submetido ao regime de subsídio e ao teto remuneratório, ao receber verba honorária (que não é indenizatória, mas sim alimentar), pois esta provém de outra fonte de pagamento, que não o Estado. Outrossim, ensejaria um nítido drible à remuneração em parcela única limitada, ao se admitir um adicional por um mesmo serviço público, que não é vinculado ao sistema de subsídio, o que certamente contraria o regime constitucional referente ao exercício do cargo público.

Logo, merece ser rejeitada a fixação de honorários advocatícios em favor do advogado público, também ante a impossibilidade de dupla remuneração por um mesmo serviço público, mediante vencimentos pagos pelo erário (geralmente mediante subsídio) e, adicionalmente, por indenização de honorários advocatícios pagos pelo contribuinte perdedor do processo, por ofensa tanto ao regime de subsídio, consoante interpretação dos arts. $39, \S 4^{\circ}, 37$, XI, e 135 da CRFB.

Corroborando o exposto, a Advogada da União Fabiana Azevedo Araújo, ainda que divergindo parcialmente quanto à natureza indenizatória da verba de sucumbência, teórica, leciona que, "nos termos da jurisprudência do Pretório Excelso e do Superior Tribunal de

12 SANTOS, Murillo Giordan. A compatibilidade do subsídio com a verba honorária de sucumbência. Revista de informação legislativa, Brasília, n. 199, p. 179-180, 2013. E, também, SANTOS, Bruno Portella dos. Os advogados públicos e o direito ao recebimento de honorários de sucumbência. Âmbito Jurídico, Rio Grande, XIV, n. 86, mar 2011. Disponível em: www.ambito-juridico.com.br. Acesso em: 25.10.2015. 
Revista Eletrônica de Direito Processual - REDP. Volume 16. Julho a dezembro de 2015

Periódico Semestral da Pós-Graduação Stricto Sensu em Direito Processual da UERJ

Patrono: José Carlos Barbosa Moreira. ISSN 1982-7636. pp. 416-435

http://www.e-publicacoes.uerj.br/index.php/redp/index

Justiça, os honorários de sucumbência possuem natureza alimentar e objetivam retribuir o trabalho exercido pelo advogado. Desse modo, estes constituem parcela remuneratória inacumulável com o subsídio, já que o art. 39, $\S 4^{\circ}$ da Constituição veda 'o acréscimo de qualquer gratificação, adicional, abono, prêmio, verba de representação ou outra espécie remuneratória'. Como a honorária não possui caráter indenizatório, nem constitui exceção constitucional, é forçoso concluir que sua percepção é proibida aos membros da advocacia pública por força do art. 135 da Carta da República"13.

Cabe destacar que, sobre o tema, na vigência da legislação processual atual, o Superior Tribunal de Justiça já confirmou que "a jurisprudência desta Corte é firme em que os honorários de sucumbência, quando vencedor o Ente Público, não constituem direito autônomo do Advogado Público, porque integram o patrimônio da entidade, não pertencendo ao Procurador ou Representante Judicial" (STJ, AgRg nos EDcl no AREsp 234618 / RS, Napoleão Nunes Maia Filho, 14.10.2014).

Fixados os três argumentos acima, não é ocioso lembrar que o art. $85, \S 19$, do novo Código de Processo Civil é no sentido de que "os advogados públicos perceberão honorários de sucumbência, nos termos de lei". Sobre tal texto legal, alguns doutrinadores têm defendido que "o NCPC pôs fim a grandes discussões, ao estabelecer a regra de que os advogados públicos também façam jus ao recebimento de honorários advocatícios"14. E, outros acrescentam que, "ao referir aos termos de lei, o dispositivo permite que legislação especial aplicável aos advogados públicos estabeleça formas distintas de percepção dos honorários, não sendo necessariamente perceptível pelo advogado público que atuou diretamente na causa a integralidade dos honorários arbitrados no processo" ${ }^{15}$.

Todavia, as três linhas argumentativas acima ensejam seja reconhecida a inconstitucionalidade material de tal preceito legal, ao menos na interpretação que significa

13 ARAÚJO, Fabiana Azevedo. A remuneração do advogado: investigações acerca da natureza jurídica dos honorários de sucumbência. Revista Virtual da AGU, n. 79, p. 4, ago. 2008. Disponível em: http://www.agu.gov.br/page/content/detail/id_conteudo/79752>. Acesso em: 26.10.2015.

14 WAMBIER, Teresa Arruda Alvim. CONCEIÇÃO, Maria Lúcia Lins. RIBEIRO, Leonardo Ferres da Silva. MELLO, Rogério Licastro Torres de. Primeiros comentários ao novo Código de Processo Civil: artigo por artigo. São Paulo: RT, 2015. p. 170.

15 AMARAL, Guilherme Rizzo. Comentários às alterações do novo CPC. São Paulo: RT, 2015. p. 158. 
Revista Eletrônica de Direito Processual - REDP. Volume 16. Julho a dezembro de 2015

Periódico Semestral da Pós-Graduação Stricto Sensu em Direito Processual da UERJ

Patrono: José Carlos Barbosa Moreira. ISSN 1982-7636. pp. 416-435 http://www.e-publicacoes.uerj.br/index.php/redp/index

a absorção de tal renda, de forma direta ou indireta, pelos advogados públicos como complementação (ou acréscimo) de seus subsídios.

E, ademais, tal preceito normativo também padece de inconstitucionalidade formal, ou seja, incorre em vício de iniciativa, por não ter se originado de projeto de lei proposto pelo Chefe do Executivo, consoante interpretação do art. $61, \S 1^{\circ}$, II, 'a', da CRFB.

No mesmo sentido, Cássio Scarpinella Bueno leciona que:

O § 19 é o mais polêmico de todos. Fruto de emenda ocorrida na Câmara dos Deputados e aceita pelo Senado na ulterior fase do processo legislativo, dispõe que os advogados públicos perceberão honorários de sucumbência, nos termos da lei. Para evitar a flagrante inconstitucionalidade do dispositivo - a remuneração dos servidores públicos, aí incluídos os advogados públicos, é tema que demandaria iniciativa legislativa do Chefe do Executivo Federal, Estadual e Municipal, consoante o caso (art. 61, § $1^{\circ}$, II, a, da CF) - importa entender a previsão inócua. Inócua porque ela, na verdade, só pode ser compreendida no sentido literal da remissão que faz. Que há ou que haverá uma lei (federal, estadual ou municipal, consoante o caso) que trata do assunto, lei esta que não é - nem pode ser, sob pena de incidir no vício anunciado - o novo CPC ${ }^{16}$.

Como se observa, não é possível o pagamento de honorários de sucumbência ao advogado público, sob a égide da legislação processual atual e, ainda, mesmo com a entrada em vigor do art. 85, §19, do novo Código de Processo Civil.

\section{Conclusões}

Em breve síntese das teses deduzidas neste artigo, cabe registrar que o primeiro item do texto desmistifica a ideia de que supostamente existiriam diversas "modalidades" de honorários advocatícios, quando, em verdade, trata-se de um conceito operacional único de remuneração profissional por um serviço específico determinado, sendo apenas o nascimento da obrigação de pagamento que difere.

16 BUENO, Cassio Scarpinella. Novo código de processo civil anotado. São Paulo: Saraiva, 2015. p. 102. 
Revista Eletrônica de Direito Processual - REDP. Volume 16. Julho a dezembro de 2015

Periódico Semestral da Pós-Graduação Stricto Sensu em Direito Processual da UERJ

Patrono: José Carlos Barbosa Moreira. ISSN 1982-7636. pp. 416-435 http://www.e-publicacoes.uerj.br/index.php/redp/index

De outro lado, a legislação processual geralmente estabelece que a parte possa ser indenizada de tal despesa, acaso seja confirmado seu interesse em juízo, mediante a inclusão de uma parcela indenizatória de forma automática no dispositivo da sentença, na exata proporção de sua vitória/derrota, consoante a articulação entre os critérios de sucumbência e causalidade. Todavia, no cenário brasileiro, a legislação processual estabeleceu que tal direito indenizatório não deve ser atribuído ao litigante vencedor, mas sim ao próprio advogado, como um prêmio de desempenho adicional, por ter auxiliado a parte na vitória. Em outras palavras, em uma análise histórica, os advogados conquistaram a indenização que pertenceria ao seu constituinte, como uma prerrogativa justificada em seu desempenho profissional, de modo a serem remunerados duplamente pelo mesmo serviço.

No concernente às discussões acerca da possibilidade de se incluir na condenação uma segunda parcela indenizatória de honorários advocatícios, desta vez em favor da parte devedora, que historicamente havia perdido o direito à indenização sucumbencial em favor do advogado, cabe destacar que tal tese não merece prevalecer, haja vista que, primeiro, não é viável impor ao litigante derrotado uma dupla condenação indenizatória (responsabilização cível em dobro), em favor do causídico e também da parte; e, segundo, de acordo com a configuração jurídica atual da sucumbência, a remuneração por contratação de causídico consubstancia uma opção negocial intransferível a outrem.

De outro lado, sobre a questão referente à fixação de honorários especificamente aos advogados públicos, ressalta-se que uma análise do sistema jurídico brasileiro revela ser inadequada e inconstitucional a condenação da parte ao pagamento de tal verba em se tratando de processo vencido por ente estatal, haja vista que, em primeiro lugar, a remuneração adicional por honorários aos advogados públicos, ainda que possa estimular o desempenho, vem em contrariedade à mentalidade de preservação de interesse coletivo que merece reger a atuação dos agentes públicos, em ofensa aos princípios da moralidade e da eficiência estabelecidos no art. 37 da CRFB; em segundo lugar, igualmente é inconstitucional a majoração da remuneração do advogado público mediante o acréscimo também de honorários, por implicar desequilíbrio na fixação da verba de contraprestação no âmbito das funções estatais, em contradição ao art. 39, § $1^{\circ}$, I a III, da CRFB, o qual estabelece os critérios para fixação da remuneração dos agentes públicos; e, terceiro lugar, é 
Revista Eletrônica de Direito Processual - REDP. Volume 16. Julho a dezembro de 2015

Periódico Semestral da Pós-Graduação Stricto Sensu em Direito Processual da UERJ

Patrono: José Carlos Barbosa Moreira. ISSN 1982-7636. pp. 416-435 http://www.e-publicacoes.uerj.br/index.php/redp/index

inconstitucional a interpretação da legislação processual que acarrete a dupla remuneração mediante subsídio estatal em parcela única e também indenização sucumbencial de cunho privado, por ofensa ao art. $39, \S 4^{\circ}$, e 135 da CRFB.

Tais argumentos ensejam seja reconhecida a inconstitucionalidade material do art. 85, $\S 19$, do novo Código de Processo Civil, ao menos na interpretação que significa a absorção de tal renda, de forma direta ou indireta, pelos advogados públicos como complementação (ou acréscimo) de seus subsídios. Ademais, tal preceito normativo também padece de inconstitucionalidade formal, ou seja, incorre em vício de iniciativa, por não ter se originado de projeto de lei proposto pelo Chefe do Executivo, consoante interpretação do art. $61, \S 1^{\circ}$, II, 'a', da CRFB.

Caberá à jurisdição, então, analisar tais argumentos e, agora em um sentido bem pragmático, definir se a maior remuneração na República Federativa do Brasil deve ser a dos Ministros do Supremo Tribunal Federal, do Presidente da República e dos integrantes do Congresso Nacional, ou alternativamente, se a renda mensal dos advogados públicos merece ser igual ou superior, sem perder de vista os critérios do art. $39, \S 1^{\circ}$, I a III, da CRFB.

\section{REFERÊNCIAS BIBLIOGRÁFICAS:}

AMARAL, Guilherme Rizzo. Comentários às alterações do novo CPC. São Paulo: RT, 2015.

ARAÚJO, Fabiana Azevedo. A remuneração do advogado: investigações acerca da natureza jurídica dos honorários de sucumbência. Revista Virtual da AGU, n. 79, p. 4, ago. 2008. Disponível em: http://www.agu.gov.br/page/content/detail/id_conteudo/79752>. Acesso em: 26.10.2015.

BUENO, Cassio Scarpinella. Novo código de processo civil anotado. São Paulo: Saraiva, 2015 .

CAHALI, Yussef Said. Honorários advocatícios. 3 ed. São Paulo: RT, 1997.

CANOTILHO, J. J. Gomes. MENDES, Gilmar Ferreira, SARLET, Ingo Wolfgang. STRECK, Lenio Luiz. (Coords.). Comentários à Constituição do Brasil. São Paulo: Saraiva/Almedina, 2013. 
Revista Eletrônica de Direito Processual - REDP. Volume 16. Julho a dezembro de 2015

Periódico Semestral da Pós-Graduação Stricto Sensu em Direito Processual da UERJ

Patrono: José Carlos Barbosa Moreira. ISSN 1982-7636. pp. 416-435 http://www.e-publicacoes.uerj.br/index.php/redp/index

CNJ. Relatório Justiça em Números. Brasília: CNJ, 2014. Disponível em:

http://www.cnj.jus.br/programas-de-a-a-z/eficiencia-modernizacao-e-transparencia/pjjustica-em-numeros/relatorios. Acessado em: 03.10.2015.

DI PIETRO, Maria Sylvia Zanella. Direito administrativo. 26 ed. São Paulo: Atlas, 2013.

MEDAUAR, Odete. Direito administrativo moderno. 13 ed. São Paulo: RT, 2009.

MELLO, Celso Antônio Bandeira de. Curso de direito administrativo. 26 ed. São Paulo:

Malheiros, 2009.

MENDES, Gilmar Ferreira. COELHO, Inocêncio Mártires. BRANCO, Paulo Gustavo

Gonet. Curso de direito constitucional. 4 ed. São Paulo: Saraiva, 2009.

SANTOS, Bruno Portella dos. Os advogados públicos e o direito ao recebimento de honorários de sucumbência. Âmbito Jurídico, Rio Grande, XIV, n. 86, mar 2011.

Disponível em: www.ambito-juridico.com.br. Acesso em: 25.10.2015.

SANTOS, Murillo Giordan. A compatibilidade do subsídio com a verba honorária de sucumbência. Revista de informação legislativa, Brasília, n. 199, p. 179-180, 2013.

THEODORO JÚNIOR, Humberto. Curso de direito processual civil. V. 1. 47 ed. Rio de Janeiro: Forense, 2007.

WAMBIER, Teresa Arruda Alvim. CONCEIÇÃO, Maria Lúcia Lins. RIBEIRO, Leonardo Ferres da Silva. MELLO, Rogério Licastro Torres de. Primeiros comentários ao novo Código de Processo Civil: artigo por artigo. São Paulo: RT, 2015. 